\title{
Militia Counterinsurgency: Implications of Pro- government Militia Participation in Counterinsurgency in Northeast Nigeria
}

\author{
Modu Lawan Gana \\ Department of Public Administration, Mai Idris Alooma Polytechnic, Geidam, Yobe State, Nigeria
}

\begin{abstract}
This article analyzed the implications of progovernment militias' participation in the counterinsurgency operation in northeast Nigeria. The militias that that has been engaged in the counterinsurgency operation since 2013 appeared influential in the reduction of the Islamist Boko Haram hostilities in the northeast. Prior to the pro-government militia participation, the counterinsurgency campaign of the State is challenged with lackadaisical performances. However, even as the militias are successful, there is still growing fear that the continued engagement of the militias has adverse consequences on the autonomy of the state and the community. This case study, therefore, investigated the implications of the militias' involvement in the counterinsurgency operation in Yobe State of northeast Nigeria. The empirical data collected through the techniques of an in-depth interview, focus group discussion, and on the site non-participatory observation. The primary data was triangulated with secondary data from published materials. The study revealed that in the absence of urgent authoritative action to regularize the militias, they will post imminent threats to the stability of the state and their immediate communities. In addition to the instigation of ethnic polarization, the militia will incubate internal feuds, hence destabilizing the peace situation of the communities. The study recommends the government to take urgent measures to verify the participants and weed bad eggs among them. The government should also provide legal procedures for their operations and recruitment process to curtail abuse and excessiveness.
\end{abstract}

Keywords: Pro-government militia; Counterinsurgency; Participations; Implications

\section{INTRODUCTION}

$\mathrm{N}$ igeria once colloquially regarded as the giant of Africa and the largest contributor to the peacekeeping and peace enforcement mission on the Africa planet appeared to a protracted insurgency by an Islamist group Boko Haram. The insurgency that began as a kind of disgruntled youth movement however turns violent in 2009 causing colossal damage to the socio-economic and political livelihood of the country. To date, conservative estimates have shown that the insurgency coupled with the brutal state counterinsurgency have claimed the lives of over 100,000 people, displaced nearly 3 million people, and rendered over 100,000 as orphans and widows (Onuoha, 2018). Indices by Global Terrorism suggest that Boko Haram's armed rebellion was responsible for 1639 terrorist attacks between 2009 and 2018 with not less than 14436 fatality rates (Global Terrorism, 2015). The rapid escalation of the violence has since scored Nigeria's Islamist as a serious security challenge since the end of the Nigeria civil war in the 1970s.

Disturbingly, the wanton destruction of the Boko Haram was recorded despite the multifaceted counterinsurgency measures by the government. Nigeria has resorted to both soft and hard approaches in its campaign. The soft campaign involved several counter-extremism campaigns through the media and religious teachings along with a series of dialogue and peace engagements with the Islamist groups. Concerning the hard approach, the government has resorted to military aggression and other quasi-military policies such as the declaration of a state of emergency in the hotbeds of the insurgents. Some estimates suggest that nearly 100,000 members of the Nigerian security forces were deployed to the northeast to counter the hostilities of the Boko Haram in the northeast (Folade, 2015). These unprecedented deployments of armed security to civil rebellion is generally believed to be the highest since the country's political independence in the 1960s. In most respect, the decisive measures have not countered the Boko Haram rebellion.

Therefore, arising from the unproductivity of the government measures, the population in northeast Nigeria caught between the devilish destruction of the Boko Haram and brutal state counterinsurgency resorted to self-defense by forming community militia groups to fight the Boko Haram. The idea initially started in Maiduguri, a city of about 2 million population. However, it subsequently escalated to other parts of the northeast region affected by the Boko Haram.

Interestingly, the group's earlier strategies are characterized in neighborhood watch; guarding streets, markets, and worship centers. However, informed by their unprecedented successes and instrumentality toward communal intelligence accesses, personal knowledge of the Boko Haram fighters, and technical knowledge of the physical terrain, the militias were coopted to fight alongside the regular securities. The military in the northeast later regiments the participants into commands and sector commands.

Shreds of evidence show the involvement of the militias has posed serious setbacks to Boko Haram fighters. For instance, in 2013, the militia chased out the Boko Haram guerillas in 
Maiduguri, by killing hundreds and apprehending many others. Since then, the hostilities of Boko Haram decrease significantly enabling the population to resume their normal lives. Omenma and Hendricks (2018) revealed that the involvement of the militia reduced the mean attack rate of the insurgent in the northeast by nearly half. For instance, between 2009 and 2013 before the mobilization of the militia, the mean attack of the insurgent stood at 11.83. However, between 2013 and 2016 after the militia participation, the mean attack rate decreased by 4.92 . In addition to the reduction in fatalities, the militias were allegedly instrumental in the rescue of several captives and aided in conquering many towns and villages occupied by the Islamist group. Besides the civil population, since 2014, the militias are pivotal for the protection of the military and their arms stocks. In March 2014, for instance, the militias repelled an attack targeted at the notorious Giwa Barrack in Maiduguri. The barrack is the largest detention facility for the Boko Haram suspect in the northeast.

Before the mobilization of the militias to the scene, the heavily armed Boko Haram successfully force the military to retreat in the battlefront. However, the militias that are wielded with mundane arms such as Dane guns, cutlasses; bow and arrow, knives, and sticks repelled the fighters while lynching catastrophe damages to the invaders. Arising from these fearless approaches of their campaigns, many people in the Nigeria northeast believe the groups' operations are influenced by charms.

Notwithstanding the unprecedented successes, the undeterred participation of people coupled with their reported cases of rights abuses, as well as the accusation of the involvement of the militias in illegitimate business activities has risen concern about the legitimacy of the militias during an in the after of insurgency. For instance, the Center for Civilians in Conflict (2019) insisted that the longer the militias remain in the battlespace, the more predatory the participant should return. The International Crisis Group in its 2014 quarterly report described the militias in Nigeria as a time bomb. These increasing concerns have risen the need for an in-debt investigation.

Although, there is a good wealth of knowledge on the counterinsurgency campaign of the militias, however, very little was known about the implications of the militias on the functioning of the State. Most of the previous works focused mostly on the successes of the militia movement in the counterinsurgency operation (Omenma and Hendricks, 2018; Bamidele, 2016). Moreover, others on the combating strategies of the participants (Gana, et al., 2018a, Gana et al., 2018b, Gana 2020; Agbiboa, 2015), as well as the motivations driving the participation of the people in the campaign (Gana, 2019). Perspectives on the implications of the militias are not adequately studies. This study intends to address this perspective. The importance of the study therefore besides its policy relevance to the Yobe State, Nigeria government, and foreign countries sharing similar militia characteristics, the findings will contribute to the evolving literature on the progovernment militias around the globe. In addressing its objective, the article proceeded in four sections. In section one, I presented the conceptual clarification of progovernment militia. Section two addresses the methodology of the study, section three presented the review of militia literature in the northeast, section four presented the implication of the pro-government militias in Yobe State, and section five is the conclusion and recommendation of the study.

\section{CONCEPTUAL CLARIFICATION}

Pro-government militias in this study refer to as a type of nonstate armed group that emerged independently of the state. However, they are linked to the government but separate from the regular forces. They support the government in its operation while the government offered some monetary and logistic support to boost its operation. In nutshell, they are third-party actors that are opposed to the anti-government militia group but are not part of the principal state security forces. Although, these categories of pro-government militias are diverse across states and regions in the Nigerian society entangled with diverse motives, the case study focus on the analysis of anti-Boko Haram militias involved in the counterinsurgency operation protecting their communities, and or fighting alongside the regular security forces in northeast Nigeria.

\section{METHODOLOGY}

This study is qualitative and it is designed on a case study. The case study was conducted in Yobe State of northeast Nigeria. The State is among the three (Borno, Adamawa, and the Yobe States) worse affected by the Boko Haram rebellion (Agbiboa, 2020). It is also a home for the two most ranked spiritual leaders (Mohammed Yusuf and Abubakar Shekau) of the movement. Whereas Yusuf is the founding leader of the group and held from Jakusko town of the Yobe, Abubakar is a deputy of Yusuf that subsequently assumed the leadership position when the former was killed during a military crackdown in 2009. Shekau was also held from the Tarmuwa local area of eastern Yobe. It was under Shekau the group assumed the violent situation. Moreover, the skirmishes of the insurgent rebellion first started in Yobe in a jungle on the Nigeria and Niger republic border. Therefore, since 2013, there is a large presence of the militias in the counterinsurgency operation of the community. Added to these are the accessibility issues of the other two States due to the potent threats of the insurgent. At the time of the research, there are pockets of reports of ambushes of civilians, blockages of highways, and abduction cases across Borno and Adamawa state thus hindering the undeterred movement of the researcher. Therefore, disrupted by these challenges, the case study was limited to Yobe state.

The fieldwork was conducted at Geidam town of Yobe State. The selection of Geidam was purposive. Much like the Yobe State, the Geidam town is one of the worst affected by the 
Boko Haram. Between 2009 and 2019, there are about twelve violent invasions by the insurgent to seize control of the town. Disturbed by the frequented attacks and the fear of the insurgent taking control of the town, in around 2014, the residents fled the town to other parts of the country as internally displaced status, and others across the country as refugees before returning after the subsidence of the violence; successes that largely attribute to the militia roles. Since 2014, there are large presences of the militias fighting alongside the government security forces. Although, the concentration of militias is notable in towns such as Gujba, however, accessibility challenges and spatial threats of the insurgents along the roads linking to the towns hinder the selection process. Arising from these challenges, the fieldwork was narrowed to Geidam town.

The empirical data was collected through triple techniques of an in-depth interview, focus group discussion (FGD), and observation techniques. The data from these sources were supplemented with data from secondary materials including journals, bulletins, newspapers, thesis, textbooks, etc. The interview is semi-structured designed with open-ended questions. It is administered on 15 participants derived from three categories of the population comprising; participants of the militia group; the officials of the local and state authorities, and community/religious leaders at the study area. The selection of the key participants was systematically guided mainly by knowledgeability, experience, and willingness to participate and contribute. The interview data triangulated with data from the focus group discussion. The FGD was held with twelve participants all derived from the interview participants. Besides the enrichment of the data, it also helped establish the reliability of the data set.

\section{LITERATURE REVIEW}

The specific accounts of when the pro-government militias started in Nigeria's' northeast is not clear. However, the popular accounts attributed the philosophy to Maiduguri, the epicenter of the Boko Haram rebellion. The idea started with the bravery of Baba Lawal Jafar, a resident of the Hausari ward in the city of Maiduguri (Bamidele, 2016; Agbiboa, 2015; Chuckwuma, 2017). Lawal infuriated by the frequented guerilla attacks of the Boko Haram around the popular Baban Layi of Maiduguri Monday market in mid-2013 foiled an impending attack of a businessman by Boko Haram fighters. With his bar hand, Lawal accosted a Boko Haram fighter wielding AK47 rifles and chains with a round of ammunition, apprehended before dragging him to the nearest regular security formation. Since then, Lawal has become a reckoning name in most parts of northeast Nigeria. Therefore, impressed by the Lawal's indomitable performance, many youths started to engage in the self-defense project. Hassan and Pieri (2018) maintained that within a short time, the philosophy spreads to other states, towns, and villages of the northeast affected by the Boko Haram.
Vigilante movement characterized the earlier strategy of the movement with the participants actively engaged in neighborhood watches, operating streets, checking motorists, and interrogating unknown passengers. With the increasing participation of people in the vigilantism, they expanded the operation to include guarding markets, worship centers, and protecting vital social infrastructures that are believed to be prime targets of the Boko Haram rebellion. The notable weapons at this stage were mainly mundanes. The majority of the participants including Baba Lawal carry sticks for his operation. Arising from the prioritization of the sticks on its operation, the local population regarded the militia as Kato da Gora, a Hausa word literally, 'men with the stick' (Agbiboa, 2015).

Consequently, the militias received national hero status in 2013 when its members organized a March movement resulting in clearing the city of Maiduguri with the remnant of Boko Haram fighters. Before the militia engagement, Boko Haram freely operate in many parts of the capital city. They mounted roadblocks to restrict regular security movements, checking passengers, and detecting suspected informants. Before the militia role, in most parts of Maiduguri, the militias live and operate tunnels rendering it difficult for air interjection, while easing them the movement of arms and logistics around its members. Therefore, interested in the growing size of the militias, the state government authorities of the affected areas officiated the movement into different units and programs. Borno State government, the hotbed of the Boko Haram, the ministry of youth development registered the participants as 'Borno Youths Empowerment Scheme (BOYES). Others are registered as 'Youth Vanguard.' In Yobe State, the movement was as 'Peace Group. Others' are however registered as 'Vigilante Group.' In Adamawa State, they are colloquially regarded as 'Sarkin Baka' literally 'hunters group.' In either case, many people in the northeast however called the participants as Civilian Joint Task Force' dubbed after Nigeria's Special Joint Task Force (STJF), and the Sub-regional Multinational Joint Task Force (MNJTF) founded by the member states of the Lake Chad Basin Commission comprising; Nigeria; Niger; Chad, Cameroun, and Benin Republics.

Therefore, with the continued successes of the group, the State governments of the affected areas provided some financial and logistics supports to the participants to ease operation. In addition to the provision of monthly stipends, several patrol vans, uniforms, and canvasses were issued to the group. The military on the other hand provided organization to the group regimenting them into the military hierarchy. They were grouped into commands and sector commands with Baba Lawal, the pioneer member serving as the overall commander of the movement. Acquainted with their technical knowledge of the physical terrain such the hills, mountains, creeks, and forests in the northeast combined with their knowledge of the Boko Haram fighters and collaborators, the militias appeared instrumental in weakening the Boko Haram hostilities. 
Agbiboa (2020) submitted that the militias are the bridgebuilder between the soldiers, whose members' are alien to the region, and the civilians that are suspicious toward the existence of the military in their communities. Therefore, the militia besides being brokers of peaceful existence, are instrumental for harnessing critical, accurate, and timely intelligence about the insurgents' movements, their hideouts, and supplies routes while sharing same with the soldiers. Impressed with the unprecedented performance, in around 2016, the Nigerian military started taking the militias to the battlefront by giving short guns, pump-machine guns, and bulletproof uniforms. Since then, the militias have become a reckoning name in the counterinsurgency operation.

Consequently, even as the militias are successful, there is increasing fear that the group will appropriate power and undermine the proper functioning of the state. Some studies have alleged that militias are using personal scores to victimize the unsuspecting population. Many others also engaged in criminal activities involving but not limited to drugs and arms trafficking. These patterns of militia threats were also evident elsewhere, such as in Afghanistan and Iraq. This case study focuses on the implications of the anti-Boko Haram militias in Yobe State of Nigeria's northeast.

The Implication of Pro-government Militia in northeast Nigeria

Empirical data revealed that there are potential threats associated with the anti-Boko Haram militias in Yobe State. The participants show that if not urgently de-radicalized, the militias would infringe on the human rights and liberties of the civil population. Informant B3 lamented:

There is an urgent need to de-radicalize them [militias], this will make the participant to be lawabiding, promote their accountability both during insurgency and in the aftermath of this insurgency. It is treacherous if we allow them to go like this, or otherwise, the government will be ready to fight another battle after the Boko Haram insurgency.

Hughes (2016) has affirmed the above assertion. The authors indicated that militias when fully acquainted with formal security functions would lose control of the government. On most occasions, militia lacks accountability for their action. Most often, their members are bedeviled with internal feuds and strife. They also lack discipline, accountability, and reliability because many of them are probably driven by different agendas and motivations. The combined effects of these further undermine the autonomy of the state. Arising from these challenges, many observers have proposed the need to de-radicalize the militias while confining their operation to establish laws of the state. Some observers have indicated that in the absence of decisive measures to checkmate excessiveness, the militias can be more dangerous than the Boko Haram group in the north (Matfess, 2017), and at worse, it can be Nigeria's next Frankenstein [monster]. Steinert et al (2018:5) opined that arming irregular forces might influence them to appropriate power thus intimidating and persecuting the civil population, while deliberately scuttling peace and disarmament processes even after the disappearance of the insurgents' threats. Humphreys \& Weinstein (2007) have insisted that engaging militias in military function can hamper the successful reintegration process even after the disappearance of the insurgent threats. Salaudeen, a notable security analyst in Nigeria's north maintained that by virtue of their youthfulness, militias might be harder to control after the insurgency. The empirical data also confirm this assertion. Informant B4 claimed;

It is very risky to let this group go back to society. They would be another time bomb. They are people that have learned how to operate the weapon. They have also have acknowledged all the weaknesses of our conventional securities. They are rubbing shoulders with the military in the combating activities, in the aftermath of this war when the soldiers are sent back to their barracks; the police cannot be able to control them. To avoid this risk, the government intends to co-opt them into the system so that they can complement the regular securities.

Supporting the above contention, informant B3 argues 'I am not a prophet, but histories have revealed that this type of youths could eventually become a serious threat to the peace and stability of the state.' In this respect, the informant insists it is tempestuous to allow the militias to go back to civilian life to remain idle. Informant reflected in the popular saying that "an idle mind is a devil's workshop." The contention of informant B3 confirmed the assertion of Bamidele (2016) and the International Crisis Group (2017). Both sources indicated militias would become a nuisance to their community in the absence of pre-emptive measures by the government. Reflecting on the previous experience, the informant argued that successive vigilante movements in Nigeria often ended up in the criminalization of their activities by converting to criminal gangsters and political thugs. This previous experience according to informant B1 interests the government to regularize the militias.

\section{Because other groups of this nature have converted to another kind of militia that further challenges the security of their respective communities. Therefore, I can say the CJTF may not be exceptional. Some of their members have already been implicating in allegations of human rights abuses. Therefore, there are fears that if no alternative employment is given, some could turn to a life of crime (Informant B1).}

Many observers have argued that militias' could end up like ECOMOG, Sara Suka, and Yan-kallare in northern Nigeria. Sources show these groups started as a vigilante movement peacefully but were later lured by criminals and elites to turn to political thugs and drug cartels this disrupting the peace and security of the host communities. In this respect, informants suggest that cannot be different in the absence of amicable 
exit for the participants in the post-insurgency period. Corroborating in this contention, informants B 1 and C3 argue that militias might be Yobe state's next security threat prophesizing that unless proactive measures were gear, they would challenge the state autonomy. In affirmation to this, Informant B1 explained:

\section{Militias should be another potential threat in the aftermath of this insurgency. Presently the government is giving them incentives both in cash and in-kind, but when the war is over and these incentives are withdrawn, the participant can look for other means for survival. We are sure to struggle for survival have repercussions on the peace and security of the population. Precisely, there is fear that many would join hands with criminal groups to threaten the local population. This can be prevented by co-opting them into the system.}

Several international organizations have documented similar trends. International Crisis Group (2017) for instance suggested that as the insurgency is reducing authorities should take appropriate mechanisms to tackle the militias to prevent them from challenging the legitimate laws and orders of the state. One mechanism of the reduction of militia threats in post-conflict periods is the disarmament, demobilization, and reintegration programs (DDR). Steinert, et al, (2018) opined that disarming militias in the post-conflict period is extremely difficult because many would not agree to surrender their weapons, it significantly symptomized with members of the militia group, because many participants' are not willing to surrender their arms in the aftermath of the insurgency.

\begin{abstract}
We cannot surrender our arms because, for many of our members, disarmament is like uncovering our clothes. In addition to Boko Haram, we are on the blacklist of almost all criminal groups because we have obstructed their livelihood. They patiently were waiting for the time when we disarm ourselves and start private life. So they can revenge. However, I am sure the government cannot attempt any kind of disarmament. Nevertheless, if they attempted we will resist it will full force (informant A3).
\end{abstract}

Although the interest for continued possession of the arms after the insurgency according to the informants is for personal safety, arming militia is one of the sources of the proliferation of illegal weapons in Nigeria (Raheem, 2015), as well as the mechanism for the frequented armed violence in the country. Nigeria is presently regarded as a host of the largest quantum of illegal firearms in Africa. Some conservative accounts have summed the number of illegal firearms in circulation in Nigeria at about 8-10 million (Onuoha, 2012; Raheem, 2015). Porous borders and the massive proliferation of firearms is allegedly fueling the growth and sustenance of the Boko Haram rebellion in the north. Most notable in the militia challenge is that their prolongation and the incentivization coupled with the skyrocketing unemployment crisis, their continued engagement would trigger similar militia groups in the country. The reality of this threat is observed with the Niger Delta militias in the southern states of the Nigeria federation. Due to the monetary incentives other associated benefits with the amnesty programs offered by the government, many other groups emerged to challenge the autonomy of the state aiming to be enlisted into the amnesty programs. A similar example was noted by the incorporation of the ethnocultural group militia 'Odudua People Congress' by the Lagos State government in the 1990s. As revealed by Reno (2002), the group engaged in outright bridges of security including looting of public and private properties, robbery, and persecution of the innocent population. This kind of accusation has since manifested with the pro-government militias in the northeast. In addition to the persecution crises, allegations are enormous about the militia's use of personal scores to victimize unsuspectingly population.

\section{V.CONCLUSION AND RECOMMENDATION}

In general, this case study revealed that the involvement of militias in the counterinsurgency operation in the northeast. Contrary to the surface benefits of intelligence collection, mounting roadblocks, and detecting suspecting fighters, the militia is equally engaged in illicit activities of collecting briefs and engaging in political activities. There is no established code guiding the militia activities. Moreover, there are no standard legal procedures for the operation. As a result, there is no semblance of accountability in the discharge of duties. Arising from their sociocultural ties with the host population by sharing all the attributes of religion and ethnicities, the militias are seemingly more accountable to their ethnic and religious leaders than to the formal state authorities. Therefore, in the absence of impromptus state action to regularize operation, militias will instigate ethnic polarization by becoming loyal and defensive to ethnic and religious followers. Presently, there is imminent division and tension among the participants, particularly on the issues regarding remuneration offers to the participants. The inequality of the remunerations in addition to lowering the morale of the fighters has constituted internal feud and gossips, a challenge if not urgently tackle is capable of further ruining the militias legitimacy and hence destabilizing the peace situation of the communities. Arising from the imminent threats of the militias, the article recommends state authorities in the northeast should establish a system in place that can ensure the adherence of militias to the highest ethical standards of wars and civil securities in their operations. A standard criterion should be establish for the recruitment of new participants aimly to obstruct the inclusion of bad eggs of the population into the operation. As there is growing suspicion on the reliability of some of the participants for selling intelligence to either the Boko Haram fighters or other criminals, there is a need for systematic verification of the participants to weed the bad elements among them. 


\section{ACKNOWLEDGEMENTS}

The author would like to thank the Tertiary Education Trust Fund (TETfund) in Nigeria for worthy of supporting the research. Thank you the Management of Mai Idris Alooma Polytechnic, Geidam for recommending the study to the TETfund. Special thanks to all the research participants that took time to give valuable information to the researcher.

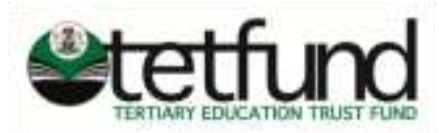

\section{DISCLOSURE STATEMENT}

No potential conflict of interest in this study.

\section{REFERENCES}

[1] Agbiboa, D. (2015). Resistance to Boko Haram: Civilian Joint Task Forces in North-Eastern Nigeria Conflict Studies Quarterly. Conflict Studies Quarterly, Special Issue 3-22.

[2] Agbiboa, E.D.(2020): Vigilante Youths and Counterinsurgency in Northeastern Nigeria: The Civilian Joint Task Force, Oxford Development Studies, DOI: 10.1080/13600818.2020.1837093

[3] Bamidele, O. (2016). Civilian Joint Task Force' (CJTF) - A Community Security Option: A Comprehensive and Proactive Strategy to Counter-Terrorism. Journal for Deradicalization, Vol. 7, pp. 124-144.

[4] Falode, J.A. (2016). The Nature of Nigeria's Boko Haram War, 2010-2015: A Strategic Analysis, Perspectives on Terrorism Vol. 10.1, pp. 41-52.

[5] Gana M.L. (2020). Militia Counterinsurgency. Perspective on the Motivations of Civilian Joint Task Force Militia Participation in Northern Nigeria. RUDN Journal of Public Administration; Vol.7 (2): 124-134. DOI: 10.22363/2312 8313-2020-7-2-124-134

[6] Gana, M.L (2019). Militia Participation in Counterinsurgency: The Impetus of Civilian Joint Task Force Participation in Combating Boko Haram in Nigeria, RUDN Journal of Political Science, Vol.21.3, pp.460-469

[7] Gana, M.L (2020). Strategy of Civilian Joint Task Force Militia in Combating Boko Haram in Northern Nigeria, International Journal of Legal Studies, Vol. 1 (7), 345-360 DOI: 10.5604/01.3001.0014.3126

[8] Gana, M.L., Samsu, K. H \& Ismail, M.M (2018a). Counterinsurgency Responses in Nigeria: Unveiling the
Constraining Challenges, International Journal of Arts Humanities and Social Sciences Vol. 3.6, pp. 1-8

[9] Gana, M.L., Samsu, K.H \& Ismail, M.M. (2018b). PopulationCentric Counterinsurgency: The Conduit for Ending Boko Haram Insurgency in Nigeria's North. European Journal of Behavioral Sciences, 1 (4): 8-13.

[10] Gana, M.L., Samsu, K.H \& Ismail, M.M. (2019). Civil Disobedience to Violent Extremism: Understanding Boko Haram in Nigeria, International Journal of Research in Social Sciences, Vol. 8(1), 1-5,

[11] Global Terrorism Database (GTD), 1970-2015. Available at http://www.start.umd.edu/gtd

[12] Global Terrorism Index. (2015). Measuring and Understanding the Impacts of Terrorism, The Institute for Economics and Peace

[13] Hughes, G. (2016). Militias in Internal Warfare: From the Colonial Era to the Contemporary Middle East, Small Wars \& Insurgencies, Vol. 27.2, pp. 196-225

[14] International Crises Group (2017). Watchmen of Lake Chad: Vigilante Groups Fighting Boko HaramAfrica Report $\mathrm{N}^{\circ} 244$,

[15] International Crises Group. (2014). Curbing Violence in Nigeria (II): The Boko Haram Insurgency. International Crises Group. Africa Report $\mathrm{N}^{\circ} 216$

[16] Matfess, H. (2016). Institutionalizing Instability: The Constitutional Roots of Insecurity in Nigeria's Fourth Republic. Stability: International Journal of Security \& Development, Vol. 5.1, 13, pp. 1-19,

[17] Omenma, J.T \& Hendricks, C.M (2018). Counterterrorism in Africa: an Analysis of the Civilian Joint Task Force and Military Partnership in Nigeria. Security Journal, 31(3), 764-794.

[18] Onuoha, C.F (2014). A Danger not to Nigeria Alone. Boko Haram's Transnational Reach and Regional Response. Fredrick Stifung Regional Office, Abuja

[19] Onuoha, F. C. (2012). Reports Boko Haram: Nigeria's Extremist Islamic Sect. Al-Jazeera Centre for Studies.

[20] Onuoha, F.C \& Oyowele, S. (2018). Anatomy of Boko Haram: The Rise and Decline of a Violent Group in Nigeria, Aljezeera Center for Studies, p. 1-10

[21] Raheem, S.O (2015). Boko Haram: The Menace of Small Arms and Light Weapons Proliferation in Nigeria. International Academic Journal of Education, Vol.1.1, pp. 16-33

[22] Reno, W. (2002). The Politics of Insurgency in Collapsing States.Development and Change Vol. 33.5, pp. 837-858

[23] Steinert, C. V., Steinert, J. I., \& Carey, S. C. (2018). Spoilers of peace. Journal of Peace Research, pp.1-15 https://doi.org/10.1177/0022343318800524

[24] Weinstein, J. (2006). Inside Rebellion: the politics of insurgent violence, Cambridge: CUP 